\title{
Factors Impacting Work Engagement of Gen Z Employees: A Regression Analysis
}

\author{
C. Christopher Lee \\ Central Connecticut State University \\ Varshini Aravamudhan \\ Central Connecticut State University \\ Tiffanie Roback \\ Central Connecticut State University
}

\author{
Hyoun Sook Lim \\ Central Connecticut State University \\ Sinéad G. Ruane \\ Central Connecticut State University
}

This study examined the factors that impacted work engagement for Gen Z employees. Six factors were identified for analysis and hypothesized to be positively related to employee engagement, including: corporate social responsibility, leadership - transformational and transactional, work-life balance, autonomy, and technology. A survey was sent out through Amazon Mechanical Turk in April 2020. From the responses, Gen $Z$ respondents accounted for 69. This study used a correlation analysis and a multiple regression analysis. Results revealed positive correlations between the variables and employee engagement, with transformational leadership showing the highest correlation and transactional leadership the lowest. Technology, autonomy, and work-life balance fell in between these two extremes. The results of the multiple regression analysis indicated that transformational leadership had the strongest influence on employee engagement, while transactional leadership had no impact. Autonomy and work-life balance were shown to have positive influences on employee engagement; technology and corporate social responsibility were not significant.

Keywords: employee engagement, Gen Z employee, transformational leadership, transactional leadership, corporate social responsibility, work-life balance, autonomy, technology

\section{INTRODUCTION}

Employee engagement is more than simply job satisfaction. When employees are engaged, they are emotionally committed to their company, which translates into real economic benefits. For instance, Kruse 
(2012) reported that companies with an engaged workforce experienced a $6 \%$ higher net profit margin than those whose employees were not. Because of the importance to companies of employee engagement, numerous studies have been conducted to identify the factors that may influence it. For instance, Wasay (2013) found that when comparing two workplaces, the organization where employees had strong worklife balance also showed a higher level of employee engagement. Regarding its connection to leadership, a recent study by Gangai and Agrawal (2017) revealed that transformational leaders are more likely to increase employee engagement. Similarly, research by Slemp and coauthors (2018) discovered a leadership style called Leader Autonomy Support (LAS), which supports autonomy in employees, led to higher employee engagement as well as numerous other positive outcomes. It is becoming increasingly important for companies to understand the factors that promote employee engagement, especially as new generations with different values and needs enter the workforce. The next set of people who will be joining the workforce is Generation Z (Gen Z). Gen Z is the youngest, most ethnically diverse and largest generation in American history, comprising 27\% of US population (Tracking Gen Z's characteristics, n.d.). According to a study by Deloitte with the Network of Executive Women, if given a choice of a boring job with high salary and an interesting job with lesser pay, Gen $\mathrm{Z}$ was fairly split over the choice (Gomez, Mawhinney, $\&$ Betts, 2020). Hence, it is important to identify the factors impacting Gen Z's engagement at work so that companies can act accordingly to retain them and their valuable skills.

The objective of this study is to identify and analyze the factors that will increase Gen Z's engagement, the newest members of the workforce. Although there are various individual studies that examine the relationship between employee engagement and such factors as effective leadership, work-life balance, autonomy, to name a few, very little research focuses particularly on Gen Z. This study proposes to fill that gap. Specifically, this research analyzes the impact of six factors: leadership (transformational and transactional), corporate social responsibility, work-life balance, autonomy, and technology on Gen Z employee engagement. The authors developed hypotheses and designed a survey to collect data via Amazon Mechanical Turk. The data were then explored using correlation and multiple regression analyses. In the next sections, a review of prior research is provided, along with the development of the current study's hypotheses. Research methodology and sample data are explained, followed by a presentation of statistical analysis. The paper concludes with a discussion of the research results, managerial implications, and potential future studies.

\section{LITERATURE REVIEW}

\section{Leadership and Employee Engagement}

To date, much research has been performed to investigate the effect of leader influence on employee engagement. For example, in a study by Parimalam and Mahadevan (2012), data related to managers' support were collected from 300 employees representing various levels (officer, cashier and executives) across 10 different banking organizations. The result of the ANOVA and correlation analyses confirmed their hypotheses that leadership has a positive relationship with employee engagement in the workplace.

While there are various studies that tie the general subject of leadership to employee engagement, considerable focus has been placed on transformational and transactional leadership approaches. Transformational and transactional leadership theory was initially developed by Burns (1978), then further refined and applied to evaluate effective leadership styles in organizational settings (Bass, 1985; Bass \& Avolio, 1990).

Transformational leadership involves four components of behaviors, namely: idealized influence; inspirational motivation; intellectual stimulation; and individualized consideration (Avolio \& Bass, 1991). Through these behaviors, transformational leaders tend to develop and align employees' individual needs and values with those of the organization, provide greater autonomy and resources of independence and power. These conditions in turn provide intrinsic motivation for employees, which is reflected in high levels of engagement in their work (Avolio \& Bass, 1991; Lee, Idris, \& Tuckey, 2019; Li, Castaño, \& Li, 2018).

By contrast, transactional leadership involves three components of behaviors: use of contingent rewards; active management by exception; and passive management by exception. Transactional leaders 
impact employee engagement particularly through contingent reward and active management by exception. Unlike the transformational leaders, transactional leaders tend to focus employees' extrinsic motivation by setting clear goals and expectations of performance and providing appropriate rewards when employees achieve goals that organization expects (Bass \& Avolio, 1993; Bass, Avolio, Jung, \& Berson, 2003; Li et al., 2018). Based on the above, the following hypotheses are proposed:

\section{Hypothesis 1a: Transformational leadership is positively related to employee engagement.}

Hypothesis 1b: Transactional leadership is positively related to employee engagement.

\section{Corporate Social Responsibility and Employee Engagement}

Drawing on their study of 673 working adults from five different regions - Canada, China (Mainland), France, Hong Kong and Singapore, Rupp, Shao, Skarlicki, Paddock, Kim, and Nadisic (2018) concluded that the positive relationship between corporate social responsibility (CSR) and employee work engagement cannot be assumed to be universal, and suggested that other individual and contextual factors play an important role. Multigroup confirmatory factor analyses (CFA) were performed to examine the configural variance and metric invariance which justified the pooling of samples. Interclass correlations were also calculated to justify the execution of individual-level hypothesis tests. As a final step, the authors controlled the effects of an unmeasured latent method to examine if common method variance threatened to bias their findings. Their results ultimately indicated that employees' CSR perceptions positively correlate with work engagement. In a different study, Valentin, Valentin, and Nafulkho (2015) developed a conceptual model to link the impact on employee engagement with the level of autonomy in CSR initiatives. To collect data for analysis, the researchers performed a Boolean search for descriptors related to employee engagement and CSR from several databases (i.e. ERIC, EBSCO, JSTOR and ABI/Inform Complete). Their findings reveal a positive relationship between employee engagement and CSR, when the employee is involved at during the planning, designing and implementation stages of the CSR initiative. Extending this examination of CSR and employee engagement, Soni and Mehta's (2020) research makes an important distinction between internal CSR (where companies take actions for the betterment of employees) and external CSR (where companies promote positive social and economic impact). For their empirical study, data were collected from 485 managers (based on multistage sampling) across 10 banks in India, and then analyzed using the Partial Least Square Equation Modeling (PLS-SEM) method. Their findings show support for a positive correlation between internal CSR and employee engagement. Drawing on the evidence from the previous empirical studies, the following hypothesis is put forward:

\section{Hypothesis 2: CSR is positively related to employee engagement.}

\section{Work-Life Balance and Employee Engagement}

Previous research has demonstrated that creating policies to promote flexibility for work-life balance increases employee engagement. For instance, Pandita and Singhal (2017) studied 123 employees from two organizations to investigate how employees' personal lives influence work engagement in the presence or absence of work-life balance policies. Employee engagement was assessed using the factors of vigor, dedication, and absorption, while levels of stress and leisure were used to operationalize work-life balance. Their results showed that organizations who create policies which offer work flexibility increase employees' feelings of work-life balance and reduce levels of stress, thereby leading to increased employee engagement. There is further evidence that while work-life balance and employee engagement are positively related, they are both negatively correlated with turnover. In their survey of 213 executives, Jaharuddin and Zainol (2019) confirmed a negative relationship between employee engagement and turnover. The authors also concluded that as employee engagement increases, the propensity to leave the organization decreases. To increase work-life balance, managers should create an open dialogue with

employees so that when personal stressors start disrupting work, managers can provide the flexibility needed to keep employees engaged. Dinh (2020) researched how the relationships managers have with their 
employees can create a greater sense of work-life balance and thus, more engagement. Survey data was collected and analyze to reveal that the employee-supervisor relationship was the most important factor to determine workload and ultimately balance organizational needs with those of the employee. Dinh (2020) concluded that the relationship with the supervisor is imperative in creating a sense of work-life balance for the employee. While it may be inevitable that employees will experience stressors in their personal and work lives, research has shown that companies can promote work-life balance through flexible working, which in turn maintains employee engagement. Moreover, organizations with greater employee engagement have lower levels of turnover and are less likely to have employees who intend to leave. Previous studies also demonstrate that the employee's relationship with manager or supervisor is also very important to foster a culture of work-life balance. Based on this past research, the following hypothesis is proposed:

Hypothesis 3: Work-life balance is positively related to employee engagement.

\section{Autonomy and Employee Engagement}

Job autonomy can increase both employee engagement and innovation. Spiegelaere, Gyes, and Hootegem (2016) studied how various dimensions of job autonomy creates different outcomes for employees. They surveyed 927 employees to study four dimensions of autonomy (i.e. work method, scheduling, work time and place of work) and how they impact employee engagement and innovation. The findings revealed positive relationships between all four components of autonomy and employee engagement and innovation. Further, Spiegelaere et al. (2016) deduced that the presence of all four autonomy dimensions was more effective for improving employee engagement than any single dimension on its own. Evidence exists that there is a positive connection between manager trust in subordinates and level of autonomy. In their study on this relationship, Heyns and Rothmann (2018) surveyed 252 employees using a number of established scales: the Behavioral Trust Inventory; Work-Related Basic Need Satisfaction Scale; and Work Engagement Scale. The researchers found that communication was a significant factor. When communication is fostered through clear expectations, employees will feel more comfortable working autonomously, consequently increasing employee engagement. In addition to managers, colleagues can play a role in creating a workplace culture that enables work autonomy. Vera, Martínez, Lorente, and Chambel (2016) investigated this topic through sample of 313 nurses in 33 work teams. Analyzing both individual and aggregated responses, they found that feelings of job autonomy were stronger when there was support from both the supervisor and team levels, resulting in higher levels of employee engagement. To summarize the previous findings in this area, work autonomy and employee engagement are positively related, and the impact on the latter is stronger when multiple dimensions of autonomy are present. Managers who trust their subordinates and foster clear, open communication will increase employees' confidence in their ability to work autonomously. Finally, employees who have support from both their peers and manager, will see an increase in their ability to work autonomously, as well as in their engagement levels. Drawing on this past evidence, the following hypothesis is offered:

\section{Hypothesis 4: Autonomy is positively related to employee engagement.}

\section{Technology and Employee Engagement}

Alnoor, Al-Abrrow, Abdullah, and Abbas (2020) examined the link between the employee perception of organizational readiness for technology change, and subsequent efficiency in using new technology. Conducting the study at a large Iraqi educational institution, the researchers collected and analyzed survey data in SmartPLS 3.0 application module, using structured equation modeling (SEM) and partial least squares (PLS) methods. Their findings indicate that a positive correlation between technology and employee engagement exist. In their 2010 study, Holt and Diggins (2010) analyzed an internal communication project within a multinational company (T-mobile) to determine if the migration of paperbased (magazine) communication to a digital platform had an impact on employee engagement. The project 
involved two phases: the first was to raise awareness of the change to the digital strategy. The second phase reinforced the change, and employees were encouraged to contribute to discussions on the digital transition.

Surprising to the researchers, $93 \%$ of employees surveyed rated their understanding of the strategy to be 'good'. The digital magazine was read by more employees than the print edition, and about $40 \%$ of the employees said that they were able to use the details published in the digital version in their sales work. The response showed that the shift to digital communication had a positive impact on employee work engagement. Maltseva (2020) also discussed ways for engaging employees in their work and the organizational environment using wearables at work. This helps both managers and employees; managers find the data collected from wearables trust-worthy, while employees can move past some physical limitations posed by such things as noise levels, temperature, and blind spots, to complete their work. Drawing from these previous studies, the following hypothesis is put forth:

Hypothesis 5: Technology is positively related to employee engagement.

\section{METHODOLOGY}

Bringing together the six hypotheses on employee engagement proposed in the previous section, the following research framework is developed, as shown in Figure 1. Measures used for testing the research variables are described next.

\section{FIGURE 1}

\section{RESEARCH FRAMEWORK}

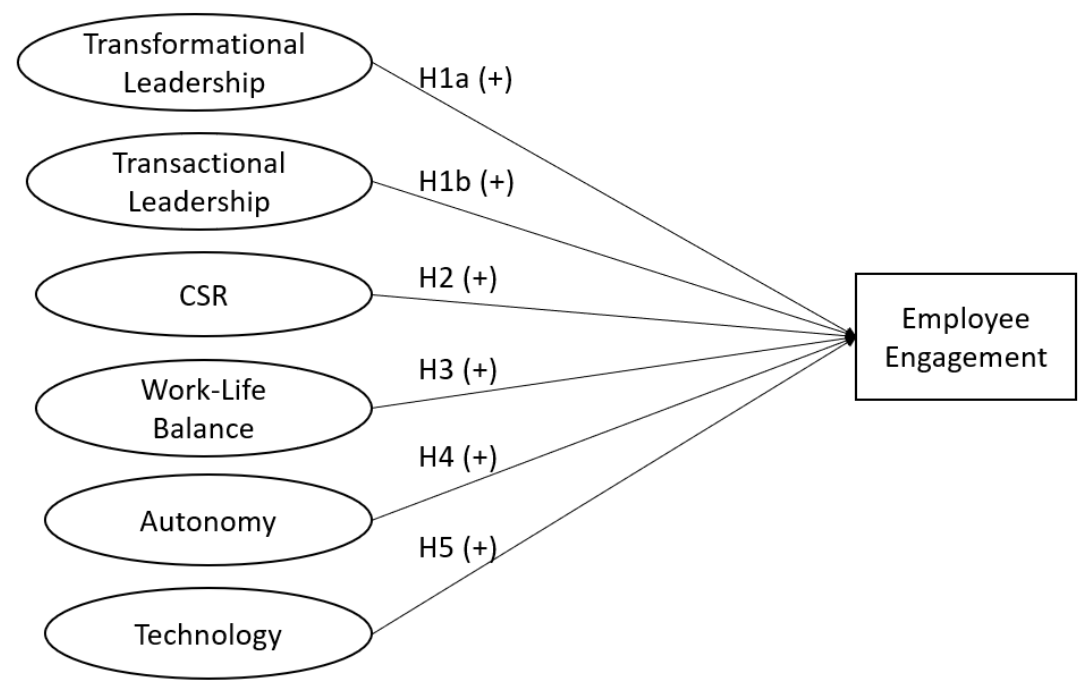

\section{Employee Engagement}

In a study designed to measure employee engagement, Schaufeli, Bakker, and Salanova (2006) identified three distinct dimensions: vigor, dedication, and absorption. For each of these three dimensions they created three items, for a total of nine items in their scale. One item from each dimension was chosen to include in the current survey, as follows: (1) I am enthusiastic about my job. (2) When I get up in the morning, I feel like going to work. (3) I feel happy when I am working intensely.

\section{Leadership}

In order to assess transformational and transactional leadership, Bass and Avolio (1993) developed the Multifactor Leadership Questionnaire (MLQ). In their measure, they identified four dimensions of transformational leadership: charismatic, inspirational motivation, intellectual stimulation, and 
individualized consideration; and two dimensions of transactional leadership - contingent rewards and management by exception. The items per each dimension included in this research questionnaire are as follows:

\section{Transformational Leadership}

Charismatic leadership dimension includes three items: (1) My leader makes everyone around him/her enthusiastic about assignments. (2) I have complete faith in my leader. (3) My leader encourages me to express my ideas and opinions. Inspirational motivation dimension includes three items: (1) My leader is an inspiration to us. (2) My leader inspires loyalty to him/her. (3) My leader inspires loyalty to the organization. Intellectual stimulation dimension includes three items: (1) My leader's ideas have forced me to rethink some of my own ideas, which I had never questioned before. (2) My leader enables me to think about old problems in new ways. (3) My leader has provided me with new ways of looking at things, which used to be a puzzle for me. Individualized consideration dimension includes three items: (1) My leader gives personal attention to members who seem neglected. (2) My leader finds out what I want and tries to help me get it. (3) I can count on my leader to express his/her appreciation when I do a good job.

\section{Transactional Leadership}

Contingent reward dimension includes three items: (1) My leader tells me what to do if I want to be rewarded for my efforts. (2) There is a close agreement between what I am expected to put into the group effort and what I can get out of it. (3) Whenever I feel like it, I can negotiate with my leader about what I can get from what I accomplish. Active management by exception dimension includes three items: (1) My leader asks no more of me than what is absolutely essential to get the work done. (2) It is all right if I take initiatives, but my leader does not encourage me to do so. (3) My leader only tells me what I have to know to do my job.

\section{Corporate Social Responsibility}

In their respective studies, Woo (2013) and the Global Reporting Initiative (GRI, 2012) presented five dimensions to evaluate corporate social responsibility (CSR): environment, human rights and labor, product responsibility, society, and economy. From their total of 12 scale items, the following 11 items were selected for this research instrument. Environment dimension includes two items: (1) Minimize pollutions when produce products/services. (2) Invest to protect environments. Human rights \& labor dimension includes three items: (1) Take care of water, energy, and material uses. (2) Minimize pollutions when produce products/services. (3) Invest to protect environments. Product responsibility dimension includes two items: (1) Clearly label/explain products/services for customers. (2) Take care of customer complaints. Society dimension includes two items: (1) Invest to develop local community welfares. (2) Avoid corruptions in business. Economy dimension includes two items: (1) Provide the company financial information to public. (2) Consider the indirect impacts of the marketing programs on society.

\section{Work-Life Balance}

In their investigation into why some managers work long hours, Brett and Stroh (2003) examined a plethora of factors, such as: housework, family involvement, family satisfaction, family to work stress, work to family stress, family alienation, work-balance life, work overload, and job satisfaction, to name a few. For the purposes of this study, the authors have opted to incorporate the work-life balance factor. The original five items from Brett and Stroh's (2003) scale chosen for this survey are as follows: (1) I feel that my job negatively affects my psychological well-being (reverse-coded). (2) I feel that my job negatively affects my physical health (reverse-coded). (3) I fell tension about balancing all my responsibilities (reverse-coded). (4) I feel that you should change something about my work in order to balance my responsibilities (reverse-coded). (5) I feel that personal commitments interfere with my job (reverse-coded). 


\section{Autonomy}

In their now-famous ground-breaking research, Hackman and Oldham (1980) explored how job structure and design can influence the work performed. Specific to this study is their analysis of autonomy, which comprise the three items: (1) I have significant autonomy in determining how I do my job. (2) I can decide on my own how to go about doing my work. (3) I have considerable opportunity for independence and freedom in how I do my job.

\section{Technology}

Nambisan, Agarwal, and Tanniru (1999) developed a 21-item scale to evaluate the impact of technology on work engagement, distinguished by three dimensions: technology cognizance, ability to explore, and intention to explore. While their full scale is composed of 21 items, only three items related to the ability to explore dimension were deemed relevant for inclusion in this questionnaire, as listed: (1) I have easy access to new technologies at workplace. (2) I am permitted to use a new technology. (3) I am capable of experimenting with new technology as necessary.

\section{Regression Model}

The present study proposes an employee engagement model using a regression analysis. The model recognizes Employee Engagement as the dependent variable, while Leadership (transactional and transformational), Corporate Social Responsibility, Work-Life Balance, Autonomy, and Technology are the independent factors. The multiple regression model is expressed as follows:

$$
Y=\beta_{0}+\beta_{1 \mathrm{a}} \mathrm{X}_{1 \mathrm{a}}+\beta_{1 \mathrm{~b}} \mathrm{X}_{1 \mathrm{~b}}+\beta_{2} \mathrm{X}_{2}+\beta_{3} \mathrm{X}_{3} \beta_{3} \mathrm{X}_{3}+\beta_{4} \mathrm{X}_{4}+\beta_{5} \mathrm{X}_{5}
$$

where $\mathrm{Y}=$ Employee Engagement

$\mathrm{X}_{1 \mathrm{a}}=$ Transformational Leadership

$\mathrm{X}_{1 \mathrm{~b}}=$ Transactional Leadership

$\mathrm{X}_{2}=$ Corporate Social Responsibility

$\mathrm{X}_{3}=$ Work-Life Balance

$\mathrm{X}_{4}=$ Autonomy

$\mathrm{X}_{5}=$ Technology

\section{Sample Data}

A multi-item questionnaire was developed based on the proposed research hypotheses and associated scales to evaluate the relevant independent variables, as previously discussed. In April 2020, survey data were collected using Amazon Mechanical Turk. Adjusting for missing values and poor response quality, a total of 69 surveys were deemed usable for analysis.

\section{RESULTS}

\section{Reliability Analysis}

Reliability tests on each variable were run with Cronbach's alpha. Apart from transactional leadership, all other variables reported strong internal consistency with over .80. To improve the reliability for transactional leadership above .7, one survey item was dropped. The results are shown in Table 1. 
TABLE 1

RELIABILITY ANALYSIS

\begin{tabular}{llllll}
\hline Variable & Items & $\begin{array}{l}\text { Item } \\
\text { dropped }\end{array}$ & $\begin{array}{l}\text { Cronbach's } \\
\text { Alpha }\end{array}$ & $\begin{array}{l}\text { Scale } \\
\text { Mean }\end{array}$ & $\begin{array}{l}\text { Scale } \\
\text { Variance }\end{array}$ \\
\hline Employee Engagement & 3 & 0 & .940 & 13.58 & 34.865 \\
Transformational Leadership & 12 & 0 & .965 & 56.94 & 327.791 \\
Transactional Leadership & 5 & 1 & .708 & 21.180 & 34.590 \\
Corporate Social Responsibility & 11 & 0 & .881 & 54.28 & 156.129 \\
Work-life Balance & 5 & 0 & .883 & 24.610 & 57.400 \\
Autonomy & 3 & 0 & .960 & 14.730 & 25.109 \\
Technology & 3 & 0 & .874 & 15.930 & 19.382 \\
\hline
\end{tabular}

\section{Correlation Analysis for Gen Z Employees}

For Gen $\mathrm{Z}$ employees, the data analysis showed that employee engagement was highly correlated with transformational leadership, transactional leadership, corporate social responsibility (CSR), work-life balance (WLB), autonomy, and technology $(\mathrm{p}<.001)$. This is presented in Table 2 below.

TABLE 2

\section{DESCRIPTIVE STATISTICS \& CORRELATION MATRIX}

\begin{tabular}{llllllllll}
\hline & Mean & SD & $(1)$ & $(2)$ & $(3)$ & $(4)$ & $(5)$ & (6) & (7) \\
\hline (1) Employee & 4.526 & 1.968 & 1 & & & & & & \\
Engagement & & & & & & & & & \\
(2) Lead_TF & 4.745 & 1.508 & $.759^{* * *}$ & 1 & & & & & \\
(3) Lead_TS & 4.355 & 1.253 & $.592^{* * *}$ & $.822^{* * *}$ & 1 & & & & \\
(4) CSR & 4.906 & 1.171 & $.553^{* * *}$ & $.584^{* * *}$ & $.512^{* * *}$ & 1 & & & \\
(5) WLB & 4.965 & 1.432 & $.594^{* * *}$ & $.448^{* * *}$ & $.315^{* *}$ & $.372^{* *}$ & 1 & & \\
(6) Autonomy & 4.937 & 1.625 & $.671^{* * *}$ & $.625^{* * *}$ & $.538^{* * *}$ & $.332^{* *}$ & $.599^{* * *}$ & 1 & \\
(7) Technology & 5.149 & 1.503 & $.436^{* * *}$ & $.434^{* * *}$ & $.374^{* *}$ & $.357^{* *}$ & .236 & $.504^{* * *}$ & 1 \\
\hline
\end{tabular}

$* \mathrm{p}<0.05, * * \mathrm{p}<0.01, * * * \mathrm{p}<0.001$ (two-tailed); $\mathrm{N}=69 ; \mathrm{SD}=$ Standard Deviation; TFL $=$ Transformational Leadership, TSL $=$ Transactional Leadership.

\section{Regression Analysis for Gen Z Employees}

A multiple regression model was analyzed to explore how the six independent variables (transformational leadership, transactional leadership, corporate social responsibility, work-life balance, autonomy, and technology) are related to the dependent variable (employee engagement). With respect to leadership, it is important to note that transformational leadership was statistically significant $(p<0.001)$, but transactional leadership was not. Autonomy and work-life balance were also found to be statistically significant $(p<0.05)$, while technology and corporate social responsibility were not. Variance inflation factors (VIF) are less than 4, which indicates that no serious multicollinearity is present in the model. The proposed regression model explained $71.3 \%$ of the variation in Gen $\mathrm{Z}$ employee engagement with the six independent variables. In summary, data fitted the regression model [Adjusted $\mathrm{R}^{2}=.713, F(6,61)=28.758$, $p<.001$ ]. Table 3 provides details of the multiple regression model results. 
TABLE 3

REGRESSION MODEL RESULTS

\begin{tabular}{lllllll}
\hline \multicolumn{5}{c}{ Dependent } & \multicolumn{6}{c}{ Variable $=$ Employee Engagement; Adjusted $\mathrm{R}^{2}=.713, \mathrm{~F}(6,61)=28.758, \mathrm{p}<.001$} \\
\hline & $\mathrm{B}$ & $\mathrm{SE}$ & $\mathrm{Beta}$ & $\mathrm{t}$ & $\mathrm{p}$ & $\mathrm{VIF}$ \\
\hline (Constant) & -2.169 & .813 & & -2.669 & .010 & \\
Leader_TF & .681 & .151 & .516 & 4.495 & .000 & 3.083 \\
Leader_TS & -.060 & .181 & -.029 & -.330 & .742 & 1.746 \\
CSR & .191 & .141 & .115 & 1.362 & .178 & 1.654 \\
WLB & .251 & .121 & .184 & 2.070 & .043 & 1.846 \\
Autonomy & .273 & .124 & .225 & 2.211 & .031 & 2.428 \\
Technology & .022 & .104 & .017 & .214 & .831 & 1.485 \\
\hline
\end{tabular}

Note: ID $=52$ was identified as an outlier and excluded. $\mathrm{B}=$ Regression coefficient; $\mathrm{SE}=$ Standard error; Beta $=$ Standardized coefficient; VIF = Variance inflation factor.

\section{DISCUSSION}

\section{Hypotheses 1a and 1b}

When considering leadership, evidence supports Hypothesis 1a - transformational leadership is positively related to employee engagement, and highly statistically significant $(\mathrm{p}=.000)$. However, the results are mixed for transactional leadership (Hypothesis $1 \mathrm{~b}$ ). The results were in line with the literature that states leadership style has a direct impact on employee engagement (Hsieh \& Wang, 2015; Busse \& Regenberg, 2019; Parimalam et al., 2012; Saad, Sudin, \& Shamsuddin, 2018; Srivatsava, 2016). In particular, these studies looked at leadership traits such as being authentic, trustworthy, and inclusive those traits associated with transformational leadership, identified by Vera and Crossan (2004). Thus, the current findings support that leadership does play an important role in any workplace for employees across generations, and Gen $\mathrm{Z}$ employees are no different. It is human nature to be inspired and engaged by leaders who have traits of transformational leadership. However, the non-significance reported here for transactional leadership may be explained by the lack of prior studies that distinguish the leadership variable between transformational and transactional styles.

\section{Hypothesis 2}

The analysis was inconclusive for Hypothesis 2 - CSR is positively related to employee engagement. The results showed no statistical significance between CSR and employee engagement $(p=0.178)$ in the regression models, while the correlations were significant. The current findings are inconclusive with the prior studies, which reported that CSR has a positive impact on employee engagement (Rupp et al., 2018; Valentin et al., 2015; Soni \& Mehta, 2020). The discrepancy could be attributed which type of CSR is examined, either internal CSR (where companies take actions for betterment of employees) or external CSR (where companies promote positive social and economic impact). The current study tested overall CSR and did not distinguish between the specific types of CSR.

\section{Hypothesis 3}

Evidence supports Hypothesis 3 - work-life balance is positively related to employee engagement. The analysis showed that work-life balance is statistically significant in relation to employee engagement $(p$ $=.043$ ), confirming past findings (Pandita \& Singhal, 2017; Jaharuddin \& Zainol, 2019). These studies found that employees who had more flexibility and a greater balance between home and work demands were more engaged. Although Gen $\mathrm{Z}$ employees may have fewer family priorities than older generations, they still want flexible work schedules and to keep the demands of their job and home life separate, in order to remain engaged at work. This study's results convey that when the balance is off, Gen Z employees will become less engaged. 


\section{Hypothesis 4}

Evidence supports Hypothesis 4 - autonomy is positively related to employee engagement, and this relationship is statistically significant $(p=.031)$. The results are in line with the extant literature that autonomy is positively related to employee engagement (Heyns \& Rothmann, 2018; Spiegelaere et al., 2016; Vera et al., 2016). These researchers contend that an environment that fosters autonomy will increase employee engagement. The present data analysis suggests that in the case of Gen $\mathrm{Z}$ employees, autonomy was only marginally statistically significant to employee engagement. A plausible explanation could be that other factors are involved in enabling work autonomy. That is, creating a sense of trust from management and feeling supported by colleagues are both important to build employees' confidence in their ability to work autonomously.

\section{Hypothesis 5}

For Hypothesis 5 that proposed a positive relationship between technology and employee engagement, the supporting evidence is ambiguous. The results showed no statistical significance between technology and employee engagement $(p=0.831)$ in the regression model while the correlations were significant. As somewhat of a surprise to the authors, these findings are inconsistent with the prior studies (Alnoor et al., 2020; Holt \& Diggins, 2010; Maltseva, 2020), which reported that technology has a positive impact on the employee engagement. It is argued that recent advances in technology further automate the employee's job, which should simply the work thus leading to greater job satisfaction. One possible reason for the deviation in results could be the smaller data sample taken up for analysis - only $31 \%$ of the participants surveyed (69 Gen $\mathrm{Z}$ people) were considered as part of this analysis. Replicating this study in the future with a larger sample size may yield different results.

\section{Managerial Implications}

The results of this study confirm and reinforce that leadership, work-life balance, and autonomy are important factors in employee engagement. Corporate social responsibility, transactional leadership and technology, however, were did not show statistical significance for improving employee engagement. Although each factor has a varying amount of influence on employee engagement, they have demonstrated benefits to increasing employee engagement.

It should also be noted that the type of leadership has a major effect on employee engagement. The current findings suggest that management should focus on a transformational leadership approach rather than transactional. To accomplish this, companies should train their managers in various leadership styles, ensuring to communicate the difference between transactional and transformational approaches. Since transformational leadership had the greatest statistically significant impact on employee engagement out of the all the variables, it is worth paying attention to how it is practiced in the workplace. One explanation may be that transformational leaders exhibit traits which are more likely to allow flexibility for work-life balance, foster clear and open communication, and build trust among employees, all which enable work autonomy. To cultivate greater employee engagement, companies are advised to implement flexible work policies to allow for work-life balance, and ensure that job descriptions promote levels of autonomy supported by their manager.

Regarding technology, organizations should motivate managers to bring innovation and change to workplace. Accordingly, managers should encourage employees to share their ideas, which in turn will inspire loyalty to the team and the organization. It is also recommended that managers mentor their subordinates, helping them during difficult situations, thus empowering employees to think in different ways to solve problems. Autonomy was also shown to be statistically significant in relation to employee engagement. One explanation for this might be that employees need to feel supported by their managers to work autonomously, and thereby more engaged. This kind of support typically comes from a transformational leader, which reinforces the positive relationship with employee engagement observed in this study. 


\section{CONCLUSION}

The current study focused on employee engagement as it pertains to Gen $\mathrm{Z}$ employees. Subsequent research may be expanded to examine and compare other age groups to determine if generational differences exist. Given that the original sample size was reduced from 214 to 69 in order to isolate the Gen $\mathrm{Z}$ responses, future studies should endeavor to obtain larger samples can so that the results can be more accurately generalized. In addition, research opportunities to explore and investigate further independent variables should be pursued. For instance, leadership is a crucial component in organizational decisionmaking, and there is a multitude of leadership types that can be studied. Finally, from a methodological perspective, prospective studies may employ multiple regression in addition to other analytical tools, such as path analysis, factor analysis, and structural equation model.

This study offers empirical support that leadership style, work-life balance, and autonomy can make a difference in how engaged workers are in their work. More specifically, the findings reveal how central leadership style is to employee engagement. Based on these arguments, companies should offer appropriate leadership training to managers and develop flexible workplace policies that will facilitate employee engagement. Engaged employee are more likely to be productive, innovative, and collaborative than nonengaged workers. And furthermore, evidence shows that an engaged workforce benefits companies with higher profits, greater returns on investment, and overall success.

\section{REFERENCES}

Alnoor, A.M.R., Al-Abrrow, H., Abdullah, H., \& Abbas, S. (2020). The impact of self-efficacy on employees' ability to accept new technology in an Iraqi university. Global Business and Organizational Excellence, 39(2), 41-50.

Avolio, B.J., \& Bass, B.M. (1991). The full range of leadership development. Binghamton, NY: Bass, Avolio \& Associates.

Bass, B.M. (1985). Leadership and performance beyond expectations. New York: Free Press.

Bass, B.M., \& Avolio, B.J. (1990). Developing transformational leadership: 1992 and beyond. Journal of European Industrial Training, 14, 21-27.

Bass, B.M., \& Avolio, B.J. (1993). Transformational leadership: A response to critiques. In M.M.

Bass, B.M., Avolio, B.J., Jung, D.I., \& Berson, Y. (2003). Predicting unit performance by assessing transformational and transactional leadership. Journal of Applied Psychology, 88, 207-218.

Brett, J.M., \& Stroh, L.K. (2003). Working 61 plus hours a week: Why do managers do it? Journal of Applied Psychology, 88(1), 67-78.

Burns, J.M. (1978). Leadership. New York: Harper and Row.

Busse, R., \& Regenberg, S. (2019). Revisiting the "Authoritarian Versus Participative" leadership style legacy: A new model of the impact of leadership inclusiveness on employee engagement. Journal of Leadership \& Organizational Studies, 26(4), 510-525.

Chemers, \& Ayman, R. (Eds.). (n.d.). Leadership theory and research: Perspectives and directions (pp. 49-80). San Diego, CA: Academic Press.

Dinh, L.N. (2020). Determinants of employee engagement mediated by work-life balance and work stress. Management Science Letters, 10(4), 923-928.

Gangai, K.N., \& Agrawal, S. (2017). Relationship between perceived leadership style and employee engagement in service sector: An empirical study. Journal of Organisation and Human Behaviour, 6(4), 1-7.

Global Reporting Initiative (GRI). (2012). Global Reporting Initiative Sustainability Report 2010/11. Retrieved from https://www.globalreporting.org/resourcelibrary/GRI-Sustainability-Report-20102011.pdf

Gomez, K., Mawhinney T., \& Betts, K. (2020). Welcome to Generation Z: Introduction. Deloitte. Retrieved from https://www2.deloitte.com/content/dam/Deloitte/us/Documents/consumerbusiness/welcome-togen-z.pdf 
Hackman, J.R., \& Oldham, G.R. (1980). Work redesign. Reading, MA: Addison Wesley.

Heyns, M., \& Rothmann, S. (2018). Volitional trust, autonomy satisfaction, and engagement at work. Psychological Reports, 121(1), 112-134.

Holt, A., \& Diggins, P. (2010). Open for business: Bringing digital engagement and strategy to life. Strategic HR Review, 9(6), 16-21.

Hsieh, C-C., \& Wang, D-S. (2015). Does supervisor-perceived authentic leadership influence employee work engagement through employee-perceived authentic leadership and employee trust? International Journal of Human Resource Management, 26(18), 2329-2348.

Jaharuddin, N.S., \& Zainol, L.N. (2019). The impact of work-life balance on job engagement and turnover intention. South East Asian Journal of Management, 13(1), 106-117.

Kruse, K. (2012). What is employee engagement. Forbes. Retrieved from https://www.forbes.com/sites/kevinkruse/2012/06/22/employee-engagement-whatandwhy/\#789de15c7f37

Lee, M.C.C., Idris, M.A., \& Tuckey, M. (2019). Supervisory coaching and performance feedback as mediators of the relationships between leadership styles, work engagement, and turnover intention. Human Resource Development International, 22(3), 257-282.

Li, Y., Castaño, G., \& Li, Y. (2018). Linking leadership styles to work engagement. Chinese Management Studies, 12(2), 433-452.

Maltseva, K. (2020). Wearables in the workplace: The new brave world of employee engagement. Business Horizons, 63, 493-505.

Nambisan, S., Agarwal, R., \& Tanniru, M. (1999). Organizational mechanisms for enhancing user innovation in information technology. MIS Quarterly, 23(3), 365-395.

Pandita, S., \& Singhal, R. (2017). The Influence of employee engagement on the work-life balance of employees in the IT Sector. IUP Journal of Organizational Behavior, 16(1), 38-57.

Parimalam, M., \& Mahadevan, A. (2012). The relationship between leadership and employee engagement: An employee course perspective. Journal of Contemporary Research in Management, 7(4), 27-35.

Rupp, D.E., Shao, R., Skarlicki, D.P., Paddock, E.L., Kim, T.Y., \& Nadisic, T. (2018). Corporate social responsibility and employee engagement: The moderating role of CSR-specific relative autonomy and individualism. Journal of Organizational Behavior, 39, 559-579.

Saad, Z.M., Sudin, S., \& Shamsuddin, N. (2018). The influence of leadership style, personality attributes and employee communication on employee engagement. Global Business and Management Research: An International Journal, 10(3), 743-753.

Schaufeli, W.B., Bakker, A.B., \& Salanova, M. (2006). The measurement of work engagement with a short questionnaire: A cross-national study. Educational and Psychological Measurement, 66(4), 701-716.

Slemp, G., Kern, R., Patrick, M., \& Ryan, L. (2018). Leader autonomy support in the workplace: A metaanalytic review. Motivation and Emotion, 42(5), 706-724.

Soni, D., \& Mehta, P. (2020). Manifestation of internal CSR on employee engagement: Mediating role of organizational trust. The Indian Journal of Industrial Relations, 55(3), 441-459.

Spiegelaere, S., Gyes, G., \& Hootegem, G. (2016). Not all autonomy is the same. Different dimensions of job autonomy and their relation to work engagement \& innovative work behavior. Human Factors and Ergonomics in Manufacturing \& Service Industries, 26(4), 515-527.

Srivatsava, S. (2016). Work deviant behavior-employee engagement: An empirical investigation of the role of ethical leadership of Indian middle level managers. Drishtikon: A Management Journal, 7(2), 53-65.

Valentin, M.A., Valentin, C.C., \& Nafukho, F.M. (2015). The engagement continuum model using corporate social responsibility as an intervention for sustained employee engagement. European Journal of Training and Development, 39(3), 182-202.

Vera, D., \& Crossan, M. (2004). Strategic leadership and organizational learning. Academy of Management Review, 29(2), 222-240. 
Vera, M., Martínez, I., Lorente, L., \& Chambel, M. (2016). The role of co-worker and supervisor support in the relationship between job autonomy and work engagement among Portuguese nurses: A multilevel study. Social Indicators Research, 126(3), 1143-1156.

Wasay, B. (2013). An investigation of the relationship between work-life balance and employee engagement: Short case studies and research papers that demonstrate best practice in rewards. Strategic HR Review, 12(4), 226-228.

Woo, H. (2013). Do consumers want a "good" apparel brand? The effects of apparel brands' corporate social responsibility (CSR) practices on brand equity moderated by culture. Unpublished master's thesis, University of North Carolina at Greensboro. 